\title{
Iranian Pre-university English Teachers' Perceptions and Attitudes towards the Iranian National University Entrance Exam: A Washback Study
}

\author{
Leila Mahmoudi \\ Faculty of Persian Literature and Foreign Languages, \\ Allameh Tabatabaee University of Tehran, Iran \\ E-mail: leilamahmoudi1979@yahoo.com
}

Kamariah Abu Bakar

Institute for Mathematical Research, Universiti Putra Malaysia

Received: 02-09- 2013

doi:10.7575/aiac.ijels.v.1n.2p.47
Accepted: 05-10-2013

Published: 31-10-2013

\begin{abstract}
The washback effect of high-stakes tests has been explored in different countries and various educational contexts. Washback generally refers to the influence of testing on teaching and learning (Alderson \& Wall, 1993). This paper which is a part of a larger study seeks to report the perceptions and attitudes of Iranian pre-university English teachers towards the effect of Iranian National University Entrance Exam (hereafter the INUEE) on teachers' English teaching and learners' English learning. The participants were 6 female pre-university English teachers from two pre-university schools in the city of Ahwaz, Iran. To investigate their perceptions and attitudes towards the INUEE, a validated questionnaire was administered to the teachers and a semi-structured interview was also conducted in order to gain richer information, and to shed more light on the data collected through their questionnaires. The respondents answered questions on whether the test motivated the students to learn English, whether the INUEE evaluated students' academic knowledge, etc. The descriptive and qualitative analysis of the data revealed that teachers' perceptions towards the test were mixed. Two teachers held positive views about the test and four other teachers held negative perceptions about this high-stakes test. The findings of this study could be pedagogically significant to policy-makers, test designers, teachers, and students.
\end{abstract}

Keywords: Iranian National University Entrance Exam (INUEE), high-stakes test, washback, perception, English teacher.

\section{Introduction}

High-stakes tests are often used as a gate keeper for the students who plan to enter universities. The INUEE is one of the competitive high stakes test in Iran. In June each year, more than one and half a million candidates (pre-university graduates) sit for this stringent and centralized nationwide university entrance exam seeking a place in one of the national universities. Since the number of seats at the universities is not matched for the number of candidates, the competition is fierce. According to Bachman and Palmer (1996) the effect of the high-stakes test could operate at either micro-level (i.e., the effect of tests on teachers and learners in the setting of classroom) or macro-level (the effect of tests on educational system and society as a whole). Given the teachers' key roles in any educational system and in washback studies, this paper seeks to investigate the pre-university English teachers' perceptions about the washback effect of the INUEE on teachers' English teaching and learners' English learning.

\section{Literature Review}

Given the crucial importance of high-stakes tests and their influences on educational systems, scholars worldwide have approached and investigated the washback effect of high-stakes tests from various perspectives in different educational contexts, and the studies have yielded variable findings. Among these studies some have looked into the teachers' perceptions towards the high-stakes tests (e.g., Cheng, 2004; Hughes, 1988; Salehi \& Yunus, 2012; Shohamy, DonistaSchmidt, \& Ferman, 1996).

In Turkey, Hughes (1988) investigated a new English test for academic purpose. He found that Turkish university English teachers' reaction towards the test was stressful and the test caused anxiety amongst them and they believed that they would have to take drastic action if they wanted their students to do well in the test. Similarly, in Israel, Shohamy (1996) and her research fellows found that teachers showed negative feelings towards the Arabic test while the EFL oral test caused "an atmosphere of high anxiety and fear of test results" among teachers. They stated that "teachers feel that success or failure of their students reflects on them and they speak of pressure to cover the materials for the exam" (pp. 309-310). The researchers attributed these different attitudes to the different status of the 
examinations (i.e. ASL and EFL). In Hong Kong Cheng (2004) studied the teachers' perceptions toward the modified Hong Kong Certificate of Education Examination (HKCEE). She reported that teachers showed positive reaction to the modified test and that their initial tensions and worries decreased. In the context of Iran, Salehi and Yunus (2012) studied the high school teachers' perceptions about the washback effect of the INUEE. The findings of their study indicated that teachers were negatively influenced by the test and they had negative perceptions about the test. Unlike the previous studies in the context of Iran, this study is deemed significant because in this study while the teachers' perceptions were asked by the questionnaire, their reasons for their positive or negative perceptions about the INUEE were investigated through the teachers' interviews as well.

Given the crucial importance of high-stakes tests and their influences on educational systems, scholars worldwide have approached and investigated the washback effect of high-stakes tests from various perspectives in different educational contexts, and the studies have yielded variable findings. Among these studies some have looked into the teachers' perceptions towards the high-stakes test (e.g., Cheng, 2004; Hughes, 1988; Ozmen, 2011; Salehi \& Yunus, 2012; Shohamy, Donista-Schmidt, \& Ferman, 1996).

Hughes (1988) investigated a new English test for academic purpose in the context of Turkey. He found that Turkish university English teachers' reaction towards the test was stressful and the test caused anxiety amongst them and they believed that they would have to take drastic action if they wanted their students to do well in the test. Similarly, In Israel, Shohamy (1996) and her research fellows found that teachers showed negative feelings towards the Arabic test while the EFL oral test caused "an atmosphere of high anxiety and fear of test results" among teachers. They stated that "teachers feel that success or failure of their students reflects on them and they speak of pressure to cover the materials for the exam" (pp. 309-310). The researchers attributed these different attitudes to the different status of the examinations (i.e. ASL and EFL). In Hong Kong Cheng (2004) studies the teachers' perceptions toward the modified Hong Kong Certificate of Education Examination (HKCEE). She reported that teachers showed positive reaction to the modified test and that their initial tensions and worries decreased. In the context of Iran, Salehi and Yunus (2012) studied the high school teachers' perceptions about the washback effect of the INUEE. The findings of their study indicated that teachers were negatively influenced by the test and they had negative perceptions about the test. Unlike the previous studies in the context of Iran, this study is deemed significant because in this study while the teachers' perceptions were asked by the questionnaire, their reasons for their positive or negative perceptions about the INUEE were investigated through the teachers' interviews as well.

\section{Methodology}

\subsection{Participants}

Six teachers participated in the study. From among six teachers, five teachers held BA degrees and one of them held MA degree in English language teaching. All the teachers were all experienced teachers and some of them had the experience of teaching at pre-university level for 13 or 14 years. The teaching experience of the participating teachers varied from 3 years to 14 years. Some general information about the teachers is provided in Table 1 below.

Table 1. General information about the teachers

\begin{tabular}{cccc}
\hline Teachers' Names & Teaching Experience & Degree & Major \\
\hline A & 6 years & M.A & EFL education \\
\hline B & 5 years & B. A & EFL education \\
\hline C & 3 years & B. A & EFL education \\
\hline D & 14 years & B. A & EFL education \\
\hline E & 13 years & B. A & EFL education \\
\hline F & 3 years & B. A & EFL education \\
\hline
\end{tabular}

\subsection{Setting of the Study}

The study was carried out in the city of Ahwaz, Iran. Six female teachers from two pre-university schools were selected from among the four pre-university schools of the city. The main reason behind choosing these six teachers was their willingness to cooperate in conducting the study.

\subsection{Instrumentation}

Two types of instruments were used in this study: teacher's questionnaire and a semi-structured interview questions which were prepared based on the feedback received from the teachers' responses to the questionnaires. The questionnaire used in Hwang's (2003) study was adopted to be used in the present study because it seemed to be the most comprehensive and relevant ones for the purpose of the study. As far as the validity of the questionnaire was concerned, it was established through a panel of experts (two university lecturers and three PhD candidates in TESOL). They reviewed and evaluated the content of questionnaire as appropriate in terms of addressing the objectives of the study adequately. Besides this, the questionnaire had already been used by Hwang (2003) in the context of Korea. In order to examine the internal consistency reliability for each subscale of the questionnaire, Cronbach's alpha was calculated. 
As for the interviews, the researcher conducted face-to-face semi-structured interviews with the teachers. In fact, the semi-structured interviews were conducted by the researcher in order to gain richer information, and to shed more light on the data collected through questionnaires. Once the interview questions were prepared based on the feedback provided by the teachers in their questionnaires, all the six teachers were interviewed; each teacher was interviewed separately for 20 minutes. The researcher wrote down all the relevant points mentioned by the interviewees during the interviews for the interview questions. It is worth noting that for the purpose of validation of the interview questions three PhD candidates in TESL were requested to evaluate and comment on the questions. A few of the interview questions were proposed to be eliminated on the grounds that the answers to them could be deduced from the teachers' responses in the questionnaire. The remaining questions were evaluated as clear and appropriate based on consensus.

\section{Results of the Study}

\subsection{Teachers' Perceptions about the INUEE}

As far as the teachers' perceptions about the purpose of the INUEE were concerned (question 17 of the questionnaire), the findings indicated that except two teachers (C \& F) who believed that the INUEE tested students' academic knowledge, the four other teachers (A, B, D, \& E) believed that the INUEE tested students' rote-memorization skill. Teachers' answers are presented in Table 2 below.

Table 2. Teachers' perceptions about the purpose of the INUEE

\begin{tabular}{lll}
\hline Q17 & YES & NO \\
\hline The purpose of the INUEE is to evaluate student's academic competence & 2 & \\
\hline The purpose of the INUEE is to evaluate student's rote-memorization & & 4 \\
\hline The purpose of the INUEE is to choose intelligent students & \\
\hline
\end{tabular}

In Q5 of the teacher's interview questions, teachers were also enquired about the purpose of the INUEE as well. Their four contradictory commented are presented below.

Teacher A: I believe that the INUEE only evaluates the students' rote-memorization skills. It is not true that the best students always pass the INUEE; there are some diligent students who have failed the INUEE many times because they always have problems in answering multiple-choice questions.

Teacher C: I believe that the INUEE represents students' academic literacy. It is obvious that those who have learned more during their course of studies can perform better on the day of exam.

Teacher E: I doubt the INUEE can really measure students' English knowledge... It only measures students' memorization ability because students' true English knowledge can't be measured within 30 minutes which is allocated for answering the English section of the INUEE...

Teacher F: I believe that the INUEE can be a valid source for determining students' academic knowledge... my students, those who managed to pass the INUEE, were very diligent and meticulous about what they were taught.

\subsection{Teachers' Attitudes towards the INUEE}

In order to understand the teachers' perceptions towards the INUEE, different questions were asked by which the teachers' attitudes about the test was investigated. For example, in teacher's questionnaire (Q20 \& Q21) they were asked whether the INUEE enriches the students' knowledge of English language and improves students' English proficiency as well. Teachers' answers to their questionnaires along with two sample verbatim quotations obtained from their interviews (Q5) are presented as follows.

Table 3. Teachers' attitudes about the test

\begin{tabular}{lllll}
\hline Q20 \& Q21 & Strongly Disagree & Disagree & Agree & Strongly Agree \\
\hline $\begin{array}{l}\text { The INUEE enriches students' } \\
\text { knowledge of English language. }\end{array}$ & 2 & 2 & 2 & 0 \\
\hline $\begin{array}{l}\text { The INUEE improve students' } \\
\text { proficiency in English. }\end{array}$ & 2 & 2 & 2 & 0 \\
\hline
\end{tabular}

As Table 3 shows, two teachers (C\& F) agreed that the test enriched the students' English knowledge and English proficiency, and the four other teachers (A, B, D \& E) either disagreed or strongly disagreed with the role of the INUEE on improving students' English knowledge and English proficiency. In their interviews (Q5) also teachers provided the reasons for their agreement or disagreement as follows. 
Teacher A: The INUEE can't help students to increase their English knowledge. I believe that they only have learnt a pile of vocabulary and English grammar for a short period of time. For example, due to practicing many sample tests my students have learnt some tricks which help them realize the correct answer even without understanding the whole sentence.... the INUEE misleads the students in their language learning. Most of my students think that if they memorize a pile of vocabulary, they would be able to cope with the test.

Teacher B: I believe that the INUEE only makes the students more skillful in answering multiple-choice questions...Most of my students go to prep schools in order to learn some strategies for answering the INUEE's multiple-choice questions. They believe that if they grasp certain techniques and learn how to manage the time, they would be able to answer the questions on the INUEE.

Teacher D: I think having a proficiency in language means being able to use that language in the real context, but we all know the INUEE doesn't prepare the students for real use of language.

Teacher F: The INUEE increases students' English proficiency. Practice makes perfect. Students learn more as they practice more sample tests...each time they learn a new thing. In fact, little by little they increase their English proficiency...

In teacher's questionnaire (Q22) they were enquired about the motivating role of the INUEE on students to study and learn English. The teachers' answers obtained from teacher's questionnaire and teachers' interviews are presented as follows.

Table 4. The motivating role of the INUEE

\begin{tabular}{lllll}
\hline Q22 & Strongly Disagree & Disagree & Agree & Strongly Agree \\
\hline $\begin{array}{l}\text { The INUEE would motivate } \\
\text { students to study English. }\end{array}$ & 1 & 3 & 1 & 1 \\
\hline
\end{tabular}

As Table 4 indicates two teachers $(\mathrm{F} \& \mathrm{C})$ either agreed or strongly agreed that the test increase students' motivation to study English and the other four teachers (A, B, D, \& E) either disagreed or strongly disagreed with the motivating role of the INUEE on students' English learning. In their questionnaire, teachers A, B, and D who were negative about the INUEE further commented as follows.

Teacher A: ...pre-university students' mind is occupied by the stress of the INUEE and this feeling of fear and distress de-motivates them to study English. Learning a foreign language should be enjoyable; otherwise, learners become disinterested in learning that language.

Teacher B: I disagree that the INUEE motivates students to learn English because they do not enjoy learning English and in their English classes they are always worried about how this or that new point would be tested on the INUEE. Students and teachers' stress reaches its peak as the time of the INUEE gets closer.

Teacher D: I don't think that the INUEE motivates students to learn English. It just makes the class atmosphere stressful and boring. For some students this test is considered as an unconquerable monster which can easily destroy their future life within a few hours.

In contrast Teachers $(\mathrm{C} \& \mathrm{~F})$ who were positive about the INUEE and believed that the test motivates the candidates to study English more and more provided their reasons as follows.

Teacher C: I believe that the INUEE pushes the students to study more English because they know that in order to secure a high rank on the INUEE, they have to study harder...

Teacher F: the test motivates them to study and learn more because they have to try more if they want to have a bright future...the test helps them to concentrate on whatever they study... it helps them to be more dutiful when they study...if they want to pass the test they should not study in a cursory manner.... 
In teacher's questionnaire (Q24), they were enquired whether the INUEE forced the students to study English harder. Furthermore, they were asked (Q25) whether they enjoyed practicing for the INUEE in their English classes. Their responses along with their additional comments are provided as in Tables $5 \& 6$ below.

Table 5. INUEE and study English

\begin{tabular}{lllll}
\hline Q24 & Strongly Disagree & Disagree & Agree & Strongly Agree \\
\hline $\begin{array}{l}\text { The INUEE forces my students to } \\
\text { study English harder. }\end{array}$ & 0 & 3 & 3 & 0 \\
\hline
\end{tabular}

Table 6. Teachers' satisfaction with practicing the INUEE

\begin{tabular}{lllll}
\hline Q25 & Strongly Disagree & Disagree & Agree & Strongly Agree \\
\hline $\begin{array}{l}\text { I enjoy the teaching of the } \\
\text { practice tests in preparation for }\end{array}$ & 3 & 0 & 0 \\
the INUEE. & & & \\
\hline
\end{tabular}

As Tables $5 \& 6$ demonstrate three teachers $(\mathrm{A}, \mathrm{B}, \& \mathrm{D})$ disagreed with the statement that the INUEE forces students to study harder and the three other teachers $(\mathrm{C}, \mathrm{E} \& \mathrm{~F})$ thought otherwise. Furthermore, teachers $(\mathrm{C}, \mathrm{D}, \& \mathrm{~F})$ and teachers $(\mathrm{A}, \mathrm{B}, \& \mathrm{E})$ either disagreed or strongly disagreed with the statement that they enjoyed practicing for the INUEE in their English classes. In fact, all the teachers expressed their dissatisfaction with practicing the INUEE in their English classes. In their questionnaires, some of the teachers expressed their discontent as follows.

Teacher B: I think practicing the INUEE is boring and tiresome...we have to teach the INUEE sample tests along with the textbook from the beginning of the semester.... the teachers who can send more students to universities would be praised by the principals and would be awarded....

Teacher D: I have to explain the INUEE points all the time during my teaching...sometimes it is so boring, but I have to practice the INUEE because all the teachers' performance is evaluated based on making their students ready for the test....almost all the people of the city know me as a good English teacher whose students always manage to pass the INUEE....

Teacher E: I don't enjoy teaching to the test, but I have to teach in favor of the test...After teaching for almost 13 years, I got assured that what counts more is the teacher's capability of better preparing the students for the INUEE...

In question 26 of teacher's questionnaire they were asked whether they felt pressure about the INUEE when they taught English in their English classes. Teachers' answers obtained from their questionnaires along with their verbatim quotations collected from their interviews (Q2) are provided below.

Table 7. INUEE and feeling pressured

\begin{tabular}{lllll}
\hline Q26 & Strongly Disagree & Disagree & Agree & Strongly Agree \\
\hline $\begin{array}{l}\text { I feel pressured about the INUEE } \\
\text { when I teach. }\end{array}$ & 0 & 0 & 2 & 4 \\
\hline
\end{tabular}

As Table 7 illustrates, all the teachers either agreed (D \& E) or strongly agreed (A, B, C, \& F) that they were under pressure and stress while they were teaching for the INUEE in their English classes. In order to find out the reasons behind the teachers' possible stress and anxiety, once again they were asked the same question in their interviews. Sample quotations obtained from teachers' interviews are presented below.

Teacher A: Practicing the INUEE tests is one of our main activities in English classes...I usually teach my students how to answer multiple-choice questions...I feel stress as much as they do because if they fail the test, it would affect my name and reputation negatively....

Teacher B: Each year I do experience the crushing feeling of stress and anxiety of the INUEE. To be honest, the principal of our school always encourages teachers to work harder for the INUEE and she admires those colleagues whose students receive high scores on the INUEE. 
Teacher C: I always feel worried about my students' test performance on the INUEE. I always think to myself whether they have been given right information and guidance about the test. And, have I sufficiently prepared them for their exam?

Teacher D: I suffer from stress and anxiety as much as the INUEE candidates do...I have shifted my emphasis in teaching from teaching what is really needed for students to practicing the INUEE sample tests...the pressures from the outside (e.g. school principal, parents, etc.) have doubled my stress.

Teacher E: Stress for the INUEE is something which almost all the pre-university teachers have experienced. I place more emphasis on test-taking strategies as well.

Teacher F: I do feel stress as much as my students do. If they pass and could manage to answer the questions easily, then I could be proud of my teaching and my students ....

In teacher's questionnaire (Q28) they were asked whether they agreed or disagreed that the INUEE should be changed. Their answers along with their sample quotations are presented below.

Table 8. Change of the INUEE format

\begin{tabular}{lllll}
\hline Q28 & Strongly Disagree & Disagree & Agree & Strongly Agree \\
\hline $\begin{array}{l}\text { The INUEE must change in some } \\
\text { ways. }\end{array}$ & 0 & 0 & 3 & 3 \\
\hline
\end{tabular}

As Table 8 indicates all the teachers agreed (A, C, \& D) or strongly agreed (B, E, \&F) that the INUEE needed to be changed. The teachers added the following further comments in their questionnaires.

Teacher B: I believe that in addition to reading skill, other three language skills (i.e., listening, speaking, and writing) should be included in the test.

Teacher E: I think that the INUEE questions are considerably harder than what the students learn from the textbook and in their English classes. It needs to be changed....

Teacher F: The test format should be changed. The INUEE should have different types of questions such as: multiple-choice, open-ended, etc.

\section{Discussion}

In this study it was found that the teachers' perceptions and attitudes about the INUEE were mixed. For some questions they had contrasting views while for some other questions all the teachers held the same negative ideas. For instance, while two teachers had positive attitudes towards the INUEE and perceived it as a test capable of evaluating the university applicants' academic knowledge, the other four teachers had negative views about the test and thought the test lacked the capacity to truly reflect the candidates' knowledge and language proficiency. The teachers with positive perceptions argued that every test has its own shortcomings and it does not sound fair and reasonable to thoroughly question the test's evaluation capacity. In their view, the test has some points of strengths and is particularly efficient when it comes to the diagnosis of the students' weaknesses, even if it is for their grammar or vocabulary knowledge. Furthermore, the test could encourage the candidates to have some kind of challenge to learn English especially for the contexts like Iran in which learning English is not obligatory for anything else (e.g., finding a job).

All the six teachers shared some negative perceptions about the INUEE. For instance, they all agreed that they were under pressure and stress while they were teaching for the INUEE in their English classes. One of the reported negative effects of the INUEE on the teachers was the psychological pressure and anxiety induced by the test. In their interviews, the teachers claimed that they were under pressure from students, parents, and school principals. They mentioned that their knowledge and commitments was evaluated based on the result of the INUEE and the number of their students who managed to pass the test. Teachers' concerns resonated with what Alderson and Wall (1993) have asserted somewhere else that, "for teachers, the fear of poor results, and the associated guilt, shame, or embarrassment, might lead to the desire for their pupil to achieve high scores in whatever way seems possible" (p. 118). Therefore, given the importance of this high-stakes test and its role on the candidates' future life, it can be considered that teachers will experience such stress and anxiety as long as the status quo exists. In her study, Shohamy (1996) also reported that the teachers had experienced high levels of pressure and anxiety because they felt that their job performance was assessed 
by students' test scores. According to Madaus and Kellaghan (1992), the effect of high-stakes tests on teachers' classroom practices is intensified when students, teachers, administrators, or the general public perceive the testing results to be linked to important decisions. These decisions include "graduation, promotion, or placement of students, evaluation, or rewarding of teachers or administrators, allocation of resources to schools or school districts, and school or school-system certification" (p. 139).

The last but not to be the least was the relationship between the teachers' teaching experience and their examorientedness. The two teachers who believed that they should spend more of class times on the INUEE-related tests and materials were the most experienced of all. One possible explanation for the existence of the relationship between the teachers' teaching experience and their exam-orientedness could be their concern about their professional reputation which could be jeopardized in the event of their students' failing the INUEE. Thus, it sounds plausible to believe that these teachers tended to be more INUEE-conscious so that they could safeguard their professional credibility in the city. Lam (1994) and Shohamy (1996) also found that experienced teachers were much more examination-oriented than their younger counterparts.

\section{References}

Alderson, C., \& Wall, D. (1993). Does washback exist? Applied Linguistics, 14(2), 115129.

Alison, J. (2005). Teachers talk about NCEA: Research report on focus groups with secondary teachers. Wellington: New Zealand Post Primary Teachers Association.

Bachman , L. F. \& Palmer, A. S. (1996). Language testing in practice. Oxford: Oxford University Press.

Bedford, J (2003). Washback-the effect of assessment on ESOL teaching and learning. Many Voices, 21, 19-23.

Cheng, L. (2004). The washback effect of a public examination change on teachers' perceptions toward their classroom teaching. In L. Cheng, Y. Watanabe \& A. Curtis (Eds.), Washback in language testing: Research contents and methods (pp. 147-170). Mahwah, NJ: Lawrence Erlbaum.

Ewing, S. C. (1998). Alternative assessment: popularity, pitfalls, and potential [Electronic version]. Assessment Update, 10, 1-2, 11-12.

Hughes, A. (1988). Introducing a needs-based test of English language proficiency into an English- medium university in Turkey. In A. Hughes (Ed.), Testing English for university study (pp. 134-146). London: Modem English Publications in association with the British Council.

Hughes, A. (2003). Testing for language teachers. Cambridge: Cambridege University Press.

Hwang, H. J. (2003). The impact of high-stakes exams on teachers and students: A washback study of the university entrance exam at the secondary school level in South Korea. Master of Arts, Digital Dissertations. Quebec: McGill University.

Lam, H. P. (1994). Methodology washback- an insider's view. In D. Nunan, R. Berry, \& V. Berry (Eds.), Bringing about change in language education: (pp. 83-99). Hong Kong: University of Hong Kong.

Madaus, G. F., \& Kellaghan, T. (1992). Curriculum evaluation and assessment. In P. W. Jackson (Ed.), Handbook of research on curriculum (pp. 119-154). New York: Macmillan.

Mizutani, S. (2009). The mechanism of washback on teaching and learning. Unpublished PhD dissertation. Auckland: University of Auckland.

Salehi, H. \& Yunus, Md. (2012). The washback effect of the Iranian universities entrance exam: teachers' insights. Jounal of Language Studies 12(2).

Shohamy, E. (1996). Test impact revisited: Washback effect over time. Language Testing, 13, 298-317.

Shohamy, E. , Donista-Schmidt, S. \& Ferman, I. (1996). Test Impact revisited, washback effect over time. Language Testing 13(3), 298-317.

Stewart, G, \& Pilcher, A. (2007). Assessment practices of level 3 NCEA teachers (2004-2006):A study of how assessment practices in the senior secondary school are evolving with standard-based assessment. Wellington: New Zealand Qualifications Authority. 